【総 説】

\title{
体力科学や体育学における健康支援研究デザインのパラダイムシフト
}

\author{
田中 喜代次 ${ }^{1)}$ 重 松 良 祐 ${ }^{2)}$
}

\section{A PARADIGM SHIFT FOR DESIGNING HEALTH-RELATED INTERVENTION STUDIES IN EXERCISE SCIENCE AND PHYSICAL EDUCATION}

\author{
KIYOJI TANAKA and RYOSUKE SHIGEMATSU
}

\begin{abstract}
Over the past two decades, a strong movement toward objective research (i.e., evidence-based medicine) has emerged in the fields of exercise science and physical education. It is now well-recognized that randomized, controlled trials (RCTs), when appropriately designed, represent the gold standard in medical studies and are usually considered of greatest evidentiary value for assessing the efficacy of interventions. RCTs are particularly effective for evaluation of drugs, devices, and procedures. In order to improve quality of reporting of RCTs, the consolidated standards of reporting trials (CONSORT) statement was developed in 1996 and use of the CONSORT statement has improved the reporting quality of RCTs over the past several years. However, RCTs are often not practical or not ethical for evaluating many public health interventions. Having a control group (no exercise, no diet, and/or no lifestyle modification) in intervention-based studies using unhealthy humans is definitely undesirable. There are viable options that should be used. For example, a trial having three groups (e.g., 1-day per week exercise group, 3-day per week exercise group, and 5-day per week exercise group) would be of more value for people with lifestyle-related diseases than having one group that does nothing. With these in mind, a paradigm shift in terms of designing health-related intervention studies for the fields of exercise science and physical education is proposed in this article.
\end{abstract}

(Jpn. J. Phys. Fitness Sports Med. 2010, $59: 457 \sim 464$ )

key word : randomized controlled trial, control group, research design, research ethic

$$
\text { I .は じめに }
$$

\section{A．体力科学や体育学の健康支援研究においてラ}

ンダム化比較試験は必須なのか

昨今，ランダム化比較試験（randomized controlled trial: RCT) や対照群設定か科学論文に強く求められ るようになった背景に，臨床試験報告に対する統合 基準 (Consolidated Standards of Reporting Trials: CONSORT $)^{1 \sim 3)}$ が発表され，ランダム化比較試験の 結果を報告するときに含めるべき22項目を示したこ とが挙げられる (2010年版 ${ }^{3)}$ では25項目) . 並行して 臨床試験登録の義務化が進み, 自然科学系の主要な
医学雑誌がRCTで得られた知見を発表する際にCON SORTを遵守するように研究者に要求してきたこと も背景にある . RCTがもっとも妥当性の高いエビデ ンスを提供する研究デザインであると位置づけた 「レベル・オブ・エビデンス」出が広く知られるよう になったことも背景の一つにある．また，日本国内 でも, 研究計画を審議する倫理委員会がRCTの方法 について詳細な説明を求めたり，研究を事前に登録 するウェブサイトがRCTであるか否かを選択する項 目を設けたりしている。これらのことから，体力科 学 (日本体力医学会誌) や体育学研究 (日本体育学 会誌) などでも，RCTがいつの間にか絶対的な（最

\footnotetext{
1)筑波大学大学院人間総合科学研究科 干305-8577 茨城県つくば市天王台1-1-1

2)三重大学教育学部

干514-8507 三重県津市栗真町屋町1577
}

Graduate School of Comprehensive Human Sciences, University of Tsukuba 1-1-1 Tennodai, Tsukuba, Ibaraki Faculty of Education, Mie University 1577 Kurimamachiya, $T_{s u}$, Mie 
高の) 研究デザインであるかのごとく錯覚するよう になってきているように想われる. 医学や薬学の分 野では, 確かにランダム化 (無作為割り付け) する ことが必須な状況もあろう．では，体力科学や体育 学の分野でランダム化は必須だろうか. 弚の是非を 吟味することなく，主要雑誌にアクセプトされたい という願望 (企図) のためだけにRCTを設定してい るケースも少なくないのではないだろうか．

2009年 5 月に開催されたヨーロッパ肥満学会で, Summerbell C. (School of Medicine and Health, Durham University, UK)は“ RCT is the only acceptable evidence?”というタイトルの講演の中で, 帯の問いに対 する回答をきっぱりNo，つまりRCTだけが受け入れ られる結果を導き出すわけではないと結論づけてい た. 臨床研究や疫学研究のルールに精通している京 都大学大学院の中山健夫教授も「RCTをおこなわな いと臨床研究として認められない」という考えは誤 っていることを指摘している5) . RCTだけにとらわ れていない公衆衛生学分野などでは今さら議論する 事柄なのかと疑問に思われるかもしれないが, 体力 科学や体育学の学会員に認識を新たにして頂きたい との思いで本稿を執筆した .

B. 健康弱者を「何もさせない対照群」に割り付 ける正当な理由はない

筆者らが以前, ある学会で高齢者の運動介入の効 果を発表したところ，「RCTで運動プログラムの有効 性を確認すべきではないか. 少なくとも対照群を設 定する必要があると思われる 」とコメントされた . 国際肥満学会においても, まったく同樣の指摘を複 数の人から受けた. 効果を科学的に厳密に追求して いくにあたって，光の研究デザインは確かに理想か もしれない、ただし, ヒ卜, 特に高齢者, 肥満や糖 尿病を有する人間を対象とする場合, 対照群の設定 には注意を払うべきである.詳細は後述するが，光 れは健康逆支援 (反支援) にもなりかねない状態を 生み出してしまう可能性が高いからである．たとえ ば，健康寿命が長くないと考えられる虚弱者や動脈 硬化が進行している肥満者, さらには生活の質もし くは人生の質 (quality of life：QoL) ${ }^{6)}$ が低下してき ている高齢者を数力月間にもわたって「何もさせな い対照群」に割り付けること，つまり何もしないこ とを期待することは明らかな逆支援となり，倫理的
に問題である . 対照群には運動教室に参加しないよ う求め, 実験群にのみ観察されうる運動の効果を多 くの研究者が報告することは, 国家 (人類) にとつ て大きな損失であると言える.一方，研究者か現時 点でベストと考えている介入内容 (運動プログラム) を対象者全員に適用することは，まさに倫理的に パーフェクトに近いものである．

統計処理の視点からも同じことが言える . データ に変化がないと予想されることをわざわざ確認する 意味で,「何もさせない対照群」を設定しておき， そ眆で, 介入群 (実験群) で変化した結果の大 きさを統計学的に認めようとするデザインは, 対照 群を設定しないことと同義と言える. 炎のような対 照群を設定する研究は当該分野のスタンダードを満 たす (自己満足) に過ぎず, 研究者 (執筆者) が強 引なロジックを巧みに打ち立てているだけで, 健康 支援の本質からは遠のくものである. 健康支援分野 における研究のミッションは, すべての人の健康や 幸福に資するものでなければならないはずである .

\section{II . 体力科学や体育学でのRCTにおける ランダム化と対照群設定の問題点}

\section{A．RCTにおけるランダム化の問題点}

通常, 研究者は目の前にいる対象者にベストな介 入プログラムを適用したいと考えている. 光して， 参加者本人も关れを希望し，研究者を信頼して集まっ ている．しかしRCTでは，個人の利益ではなく母集 団の利益のため, すなわち未来の人たちの利益を想 定しているため，結果的に目の前にいる参加者に「一 働き」してもらうことを求めている7).これは体力 科学や体育学に限ったことではなく, ヒトを対象に した学問に共通する問題である . 現代の学問はこの ような問題を内包しながら発展していることを常に 念頭に置きつつ, 謙虚な態度を示すべきである．

RCTを倫理的に成立させる条件は 20 年以上も前に 示されている8). 兴れによると，どちらの介入プロ グラムが劣っているかを判断しかねる場合に臨床的 平衡 (clinical equipoise) があるとされ, 少の場合 に限ってRCTデザインを採用しても良いとしてい る.このことを踏まえると，RCTをおこなう場合， 研究者は実験プログラムと対照プログラムのいずれ か効果的なのかを真に判断しかねている状態でなけ ればならない．しかし, 体力科学や体育学での健康 
支援研究では, 明らかに優劣を区別できている $2 つ$ のプログラムを比較することがほとんどではないだ ろうか.これは健康逆支援の実態と言えよう．

\section{B. 対照群設定における問題点}

RCTを含むすべての介入研究における対照群の設 定条件についても，医学の分野では示されている「「当 然ながら, 新しい治療法より劣っていることが分かっ ている治療法は選べない，光の時の最も効果のある 治療法を選ぶべき」 ${ }^{9 \sim 10)}$ とされていることから, 臨 床研究では「何もさせない対照群」を設定すること はきわめて稀である.乥して，「プラセボまたは無治 療群において, 参加者が治療をまったく受けないの ではない11)」ことはあまり知られていないように思 われる. 产のため, 臨床試験をおこなう研究ではプ ラセボ主1)あるいは無治療を対照とする研究は, 必ず しも非倫理的ではないとも解釈されている ${ }^{10)}$.ただ し, 光の前提には, 試験の実施状況か強制的かつ強 圧的ではなく, すべての治療の選択肢と, 治療を遅 らせることによって起こりうる結果が参加者に十分 に説明されていることが求められている(11).このよ うな対照群には緩和療法 (たとえは鎮痛薬) や最良 のサポーティブ・ケアが提供されることになる .

ところか対照群の概念が体力科学や体育学の分野 に持ち込まれると，何もさせない(あえて運動させ ない) ことがなぜか無意識のうちに対照群のプログ ラムに位置づけられてしまう．弚の理由は，一部の 先行研究のデザインを熟慮なく真似しているからで はないだろうか．実は，筆者らも光のような条件の 下で研究をおこなったことがある．すなわち，介入 (運動する) 群と無介入 (運動させない) 群を設定 した．乥して，光れ光れの起こりうる結果を事前に 説明した . 光の後, 参加者をいずれかの群に無作為 に割り付けたが, 運動させない群に配置されること が分かった時の参加者の落胆の樣子に心を痛めた . 運動から遠のかせているという罪の意識さえ覚え た.さらに, 兴の群のコンプライアンスがあまり高 くないことも経験した .これらのことから筆者らは， 臨床試験の一条件を単に真似するだけでは，健康支 援の本質からは遠のくことを改めて認識した . 政府 から助成を受けた研究という名目 (大義) をふりか ざして, 参加者が希望するにも関わらず運動させな いという研究デザインを心の底から正当化できなく
なったのである .

運動は健康保持に役立つと研究者自身が考えてい るのであれば，運動させない期間を設けることは正 当化できず，「何もさせない対照群」を設定するは ずはない．しかし現状では対照群を設定することが 多く，兴のことが正当化されている．ヒトを扱う研 究者はこのことを改めて問題視し, 研究デザインを 再構築すべきである. 改善の必要性の高い高齢者や 肥満者, 糖尿病等の有疾患者を対象にする場合,「何 もさせない対照群」を設定することは特に正当化で きない .

運動させる群と運動させない群の 2 群を設定し， 運動させない群に後日運動させるという方法があ る .この方法はクロスオーバー計画と呼ばれ，後日 に運動させられることから，「何もさせない対照群」 の設定を正当化できると主張されている . しかし， 弚れでも正当化できないのではないか，弚の理由は， 研究者が運動の意義を認めている以上, 運動させな い期間を設定する根拠が著しく乏しいためである． 特に高齢者の体力や身体機能は，発育期にある児童 の弚れらとは対照的に，余命期間が短いなかで日々 衰退している実情を認識しなければならない .

臨床試験では，対照群に提供する治療方法が $4 つ$ に分類されている11).すなわち(1)プラセボ , (2)無治 療，(3)異なった用量または用法の被験治療，(4)被験 治療とは異なった実薬による治療, である。体力科 学や体育学において(1)は設定困難で, (2)は上述した ように不適であり，(31設定可能である .たとえば， 減量教室に参加する肥満者が介入前の摂取エネル ギー量から $1200 ， 900 ， 600 ， 300 \mathrm{kcal} /$ 日を減らす という 4 群のいずれかに割り付けられる, という研 究方法は倫理的に許容されよう ${ }^{12)}$. (4)に近い例とし て，近年では虚弱な高齢者の身体機能向上にストレ ッチが提案されているが , これを実験群に位置づけ， 対照群にはレジスタンストレーニングを提供すると いったデザインが考えられる．しかし，栄養学と同 樣, 運動も多樣な要素 (体操・ストレッチ, 有酸素 運動，レジスタンス運動，レクリエーションなど) を組み合わせることによるバランスを重要と考える のであれば, ストレッチのみとレジスタンスのみの 2 種目で介入研究をおこなうことの意義を吟味する べきかもしれない .

実際におこなわれている体力科学の研究にも良い 
デザインが散見される．たとえば, 筑波大学・JA茨 城県厚生連生活習慣病学寄附講座が減量に関する介 入研究を実施している ${ }^{13)}$. 兴の研究目的は, 動機づ け支援や資料提供, 集団型減量支援といった減量プ

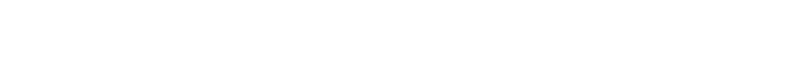
る. 少のために強介入群, 弱介入群, 対照群の 3 群 を設け，群によって構成要素の種類を変えている． すなわち, 強介入群に対しては動機づけ支援, 資料 提供, 集団型減量支援 ( 3 種類) , 弱介入群に対して は動機づけ支援, 資料提供 ( 2 種類) , 光して対照群 には動機づけ支援 (1 種類) を提供している.対照 群には介入を何もおこなわないのではなく，特定保 健指導 ${ }^{14)}$ で定められている最低限の支援プログラ ム，つまり動機づけ支援を展開している．このよう な研究デザインには対象者を思いやる姿勢があると 言えよう。

\section{III . 新しい研究デザイン・考え方の確立}

A. 日本独自, そして体力科学・体育学独自の考 え方が必要だろう

研究条件に同意してもらったとしても，ジョギン グしたい人にウォーキングをさせること，あるいは 運動好きな人に運動させないこと等, 個人の意思に 反する無作為割り付けを妥当とする研究思考光のも のに無理があるのではないか. 換言すれば, 同意が あればどんな研究デザインでも良いのだろうか．研 究者に寄せられている参加者の期待や信頼に, どの ように応えようとしているのか . アルコールを飲め ない人に強要するかのような, あるいはカラオケが 苦手な人に懇願して歌わせるような，つまり個人の 意思を無視した研究は質が高いとは言えない．しか し, 多くの研究者はこのようなアプローチこ光が最 高級の研究だと誤信しているように感じる . 一部の 研究者は日本でのRCTは困難であるという倫理観を 持っているが, 我が国全体あるいは体力科学や体育 学の組織独自の倫理観はどうであろうか.アメリカ スポーツ医学会による勧奨メッセージ" Exercise is Medicine” ) に反するかもしれないが ,「運動嫌いの 人に運動を強要しない」という倫理観に基づいた研 究を進めていくことも必要であろう. 医学の倫理観 (研究指針) にとらわれず, 体力科学や体育学独自 の倫理観 (研究指針) を打ち出すべきではないだろ うか. 光して, 光の指針に基づいて真に価値ある研
究をデザインし，対象者の倫理的配慮を施せば良い のである

\section{B. 柔軟な考え方や広い視野も必要である}

RCTの特長は, アウトカムに及ぼす交絡要因の影 響を防ぐことにある．とのため, 異なるデザインで 研究を実施した場合は炎の知見にlimitationがあるこ とを意識し，別の研究でそれを補うように努めるの が良いであろう．種々のバイアスを少しでも補正で きるような情報を得ることも必要と言える ${ }^{15)}$.

医学分野では状況に応じて柔軟な研究デザインが 採用されている．たとえば，外科手術を伴うような 場合は二重盲検化注 2$)$ が困難であるため, 単盲検で 十分とされている ${ }^{11,16)}$. また，重篤な疾患に対し て優越性試験によって有効であることが示されて いる治療法が存在する場合, プラセボ対照試験は 非倫理的と考えられることがある16).さらに，EBM (evidence-based medicine) の構築にあたっては必ず しもランダム化比較試験やポジティブ知見に偏った メタアナリシスの結果に縛られるのではなく，弚の 時の疑問に対する回答が得られる最良の方法に基づ くことか望ましいとしている17).メタアナリシスに 限界注3) があることも踏まえると, 体力科学や体育 学の分野では柔軟な考え方と広い視野を見習う必要 があろう.

論文公表の意義が強調されるなか, パブリケーシ ヨンバイアスが懸念されていた点に関しても, 対策 か講じられるようになってきている.具体例を挙げ よう．食物や健康に関する情報は，一般の二ュース とは違って「有効／効いた」という話が多く，「無 効／効かない」という情報はあまり伝わらない．た とえばある総説において, 野菜や果物など食物類や ワイン類の有効性か認められるとは言えないという ことが主たるメッセージであるにもかかわらず，光 こに引用されている少数の「有効である」と述べた 研究成果のみを部分的に取り上げ, 兴のことを強調 して伝えてしまうという事例もある.読者の目を引 き付けるべく見出しを強調すると, 内容に過度のバ イアス (偏見) がかかってしまうのである．また， 編集や校正の段階でも，インパクトを高めてわかり やすくするための行き過ぎた操作 (表現上の化粧) が，著者自身または他者によってなされてしまうこ ともある. 東北大学公共政策大学院の坪野吉孝教授 
は ,一つのポジティブ情報の背後には，伝えられな いネガティブ情報がたくさんある場合も多いことを 知っておいてほしいとコメントしている . 例が長く なったが，この点に関して，昨今の臨床試験登録で はネガティブデータであっても結果をきちんと入力 することを求めることで, パブリケーションバイア スの抑制に努めている．このように，医学分野では 適正な医療の発展につながる独自の仕組みをつく り，不足点があれば常に改善する姿勢をとっている． ここからわれわれが学ぶ点は多い.

\section{C. 非劣性検定や同等性検定の活用}

柔軟な考え方は統計処理においても活かされてい る、薬剂を例に挙げる、薬剂の有効性の指標に現れ ない他の利点，たとえば実験薬では服薬頻度が少な くなるというメリットがある場合, 実験薬か対照薬 に比へて有効性が優れていることだけにこだわる必 要はない．この場合，実験薬の有効性が「少なくと も同等」,すなわち「劣っていない」ことを検証すれ ば良いのである ${ }^{9)}$. 光の検証には非劣性検定や同等 性検定が用いられている .

このような考え方や統計処理法を導入することで， 有効性を確認する手段は比較しかないという研究思 考から離れてみるのも良いかもしれない. 乥うすれ ば, 運動させないという対照群を設定する研究デザ インにとらわれなくなるであろう．次節では，光の ような「とらわれていない」研究デザインの例を挙 げる

\section{D. 現場への適用を見据えた研究デザインの例}

以下は, 種々の条件を統制できる実験室レベルで の研究,つまり結果の信頼性 (再現性) を重視した 研究ではなく，条件を統制できない現場での実施可 能性を見据えた公衆衛生学分野における健康支援研 究のデザインであり, RE-AIM ${ }^{18 \sim 19)}$ と呼ばれてい る.介護予防を目的にした研究におけるRE-AIMの 例を挙げる .

RE-AIM は REach（光の地区の何\%の高齢者に光の プログラムを適用できるか), Adoption（何\%の地区が そのプログラムを導入したか), Implementation（プロ グラム内容がどの程度浸透したか), Effectiveness（プ ログラムはどの程度効果的であったか), Maintenance (光の地区および参加者本人の継続希望はどの程度か)
の 5 領域からなっている．つまり，厳密な手法を用い て得られた研究の知見を, 地域の健康づくりに広く 展開していけるか否かについて検証するフレーム ワークがRE-AIMなのである .このフレームワーク を用いると，RCTなどの概念だけに縛られることな く，健康支援研究を推進できると思われる．これま では実験室レベルでの研究報告が多く，また，弚の ような研究が奖励される傾向もあったが，乥れとは 異なる視点に立った，質的により高い研究を進めて いく必要があると思われる .

$$
\text { N.さいごに }
$$

体力科学や体育学における健康支援研究は, さま ざまな分野の研究知見や現場での実施可能性を考慮 して展開されるため, RCTのような研究ばかりが求 められているとは限らないことをもつと認識すべき であろう.実際，1970年から1980年代にかけては観 察研究がRCTに比べて介入の有効性を過大評価する と指摘されていたが，2000年以後には両者に大きな 違いは見いだされないとする論文が発表されるよう になってきている5). 本稿ではRCTによる介入研究 について言及したが, 今後は観察研究のパラダイム シフトも必要に応じて提案していきたい．

要介護化や生活習慣病の一次予防を唱える研究で あれば，何もさせない対照群の設定よりも，目の前 の健康弱者を真摰に思いやる気持ちを大切にすべき である．乥れが本来の健康支援（倫理的配慮）では ないだろうか．今までのやり方では，体力科学や体 育学における健康支援研究は医学, 疫学, 心理学, 生理学などの親学問と言われる他分野から発信され る情報に振り回されてしまい, アイデンティティを 見失う危機に曝されていると感じる.今こ光，体力 科学や体育学の取り組むべき独自の課題と方法論 を，倫理という物差しの上で見直すべきときではな いだろうか.

体力科学や体育学における健康支援研究が年々増 えているが, 光こにはパラダイムシフト (発想・着 想・認識などの見直しや転換) が必要である．さら に，皆が同じような研究を繰り返すのではなく，研 究者 (研究施設) の持つ得意分野で力を発揮し, 光 れを総合して我が国の健康支援研究を推進していく ことも必要と思われる . 関連学会でこのようなシン ポジウムが開催され，議論が活発に交わされること 
を期待したい 。

注 1

プラセボとは, 色, 重さ, 味および匂いといった 物理的特性を可能な限り被験薬に似せた, 試験薬を 含まない「ダミー」を意味する ${ }^{11)}$.

注 2

二重盲検化とは「各被験者に割り付けられた治療 を被験者及び医師も知らないこと」である。単盲検 とは「各被験者に割り付けられた治療を被験者のみ が知らないこと」である ${ }^{11,16)}$.

注 3

筆者の一人 (田中) が収集した過去30年間のデー タを総合すると, HDLコレステロールは最大酸素捸 取量との相関がもつとも高い $(r=0.72)$. 特にマラ ソンランナーのHDLコレステロールが高いことか ら，顕著な効果をあげるには運動時間を長くするこ とが必要だろうと言える.この結果を念頭に置いて メタアナリシスをおこなうと「HDLコレステロール の増加には運動時間が鍵となる」と結論づけられよ う.確かに, メタアナリシスは類似のリサーチクェ スチョンに対する類似の研究の知見を統合するもの で, 最大公約数的な知見を得る上では有用とされて いる.しかし光れゆえに, 個々の研究の特性をデー 夕統合に際して，必ずしも反映できているとは限ら ない，たとえば太極拳，アクアビクス，バレーボー ル, 卓球, ダンス, 柔道, 剣道, 登山など種目が異 なれば，運動時間だけでは説明が困難になる．この ような限界を知った上で結果を解釈することが適切 と考えられる .

光も光も運動の有益性を享受するには, 楽しみ (脳 が快適さを感じ) ながら運動を習慣化することにつ きる．しかし，メタアナリシスでは谷の要素がない がしろにされてしまいかねない可能性に留意すべき であろう。

\begin{abstract}
謝 辞
本稿の完成にあたり，有益なご助言をくださいました中 山健夫先生 (京都大学大学院医学研究科) と中田由夫先生 (筑波大学大学院人間総合科学研究科) に感謝の意を表し ます．
\end{abstract}

(受理日 平成 22 年 7 月 27 日)

$$
\mathrm{V} \text {. 文献 }
$$

1) Begg C, Cho M, Eastwood S, Horton R, Moher D, Olkin I, Pitkin R, Rennie D, Schulz KF, Simel D, Stroup DF: Improving the quality of reporting of randomized controlled trials. The CONSORT Statement. JAMA, 276, 637-639, 1996.

2) Moher D, Schulz KF, Altman D, CONSORT Group (Consolidated Standards of Reporting Trials): The CONSORT statement: revised recommendations for improving the quality of reports of parallel-group randomized trials. JAMA, 285, 1987-1991, 2001.

3) Moher D, Hopewell S, Schulz KF, Montori V, Gøtzsche PC, Devereaux PJ, Elbourne D, Egger M, Altman DG: CONSORT 2010 explanation and elaboration: updated guidelines for reporting parallel group randomised trials. BMJ. 340: c869. doi: 10.1136/bmj.c869, 2010.

4) 中山健夫: EBMの手法を用いた診療ガイドライン：日 本における取り組み・課題と展望. 日本補完代替医療 学会誌, 2 , 113-125, 2005. Nakayama T: Clinical practice guidelines developed according to the principles and methodologies of evidence-based medicine (EBM): Real movements, problems and future prospects in Japan. Japanese Journal of Complementary and Alternative Medicine, 2, 113-125, 2005.

5) 中山健夫: 臨床研究から診察ガイドラインへ: 根拠に基 づく医療 $(\mathrm{EBM})$ の原点から.日本耳鼻咽喉科学会会 報, 113，93-100，2010。

6) 田中喜代次, 重松良祐: 高齢者に対する健康支援. In: 健康支援学入門, 日本健康支援学会編集, 東京: 北大 路書房, 2001, 91-101.

7) 津谷喜一郎, 石川陸男: Evidenceと臨床試験 . 日産婦 誌, 51, N223-227, 1999.

8) Freedman B: Equipoise and the ethics of clinical research. N Engl J Med, 317, 141-145, 1987.

9) 丹後俊郎: 無作為化比較試験. 朝倉書店: 東京, 1-30, 2003.

10) World Medical Association: World Medical Association Declaration of Helsinki: Ethical Principles for Medical Research Involving Human Subjects. (http://www.wma.net/e/policy/b3.htm), 2008.

11）厚生労働省医薬局審査管理課長: 「臨床試験における 対照群の選択と光れに関連する諸問題」について。 (http://www.pmda.go.jp/ich/e/e10_01_2_27.pdf), 2000.

12) 田中喜代次, 重松良祐: これからのスポーツ健康科学 の研究における新しいコントロール群設定の提案 . 体育学研究, 48, 45-47, 2003. Tanaka K, Shigematsu R. A new research protocol without a" classical control group" in health \& sport sciences. Japan Journal of Physical Education, Health and Sport Sciences, 48: 45-47, 2003. (in Japanese)

13) 中田由夫, 岡田昌史: 減量プログラムにおける資料提 供と集団型減量支援の効果検証一研究デザイン一. 日 本公衆衛生雑誌，57 (9)：835-842，2010．Nakata Y, Okada M: Effects of weight-loss tools and a group-based 
weight-loss support program: Rationale and study design of a randomized controlled trial. Nippon Koshu Eisei Zasshi. In press. (in Japanese)

14 ) 厚生労働省保険局: 特定健康診査 - 特定保健指導の円 滑な実施に向けた手引き。

(http://www.mhlw.go.jp/bunya/shakaihosho/iryouseido01/ info03d.html ), 2008.

15) Thomas JR, Nelson JK著 (田中喜代次, 西嶋尚彦監訳): 身体活動科学における研究方法. 東京 : ナップ, 2004 .

16) 厚生省医薬安全局審査管理課長:「臨床試験のための 統計的原則」について。

(http://www.pmda.go.jp/ich/e/e9_98_11_30.pdf), 1998.

17 ) 坂本純一, 大庭幸治: EBMにおけるランダム化比較
試験 . Tenri Medical Bulletin, 8, 90-91, 2005.

18) Glasgow RE, Vogt TM, Boles SM: Evaluating the public health impact of health promotion interventions: the RE-AIM framework. Am J Public Health, 89, 1322-1327, 1999.

19) Li F, Harmer P, Glasgow R, Mack KA, Sleet D, Fisher KJ, Kohn MA, Millet LM, Mead J, Xu J, Lin ML, Yang T, Sutton B, Tompkins Y: Translation of an effective tai chi intervention into a community-based falls-prevention program. Am J Public Health, 98, 1195-1198, 2008. (RE-AIMはhttp://www.re-aim.org/に詳しく解説され ている) 